\title{
Furosemide stress test as a predictive marker of acute kidney injury progression or renal replacement therapy: a systemic review and meta-analysis
}

\author{
Jia-Jin Chen \\ Linkou Chang Gung Memorial Hospital \\ Chih-Hsiang Chang \\ Linkou Chang Gung Memorial Hospital
}

\section{Yen Ta Huang}

Division of experimental surgery, Department of surgery,Hualien Tzu Chi Hospital

George Kuo ( $\sim$ b92401107@gmail.com )

Chang Gung Memorial Hospital Linkou Branch https://orcid.org/0000-0002-5908-403X

\section{Research}

Keywords: Furosemide stress test, acute kidney injury, severity prediction

Posted Date: April 15th, 2020

DOI: https://doi.org/10.21203/rs.2.23355/v2

License: (c) (i) This work is licensed under a Creative Commons Attribution 4.0 International License. Read Full License

Version of Record: A version of this preprint was published at Critical Care on May 7th, 2020. See the published version at https://doi.org/10.1186/s13054-020-02912-8. 


\section{Abstract}

Background: The use of the furosemide stress test (FST) as an acute kidney injury (AKI) severity marker has been described in several trials. However, the diagnostic performance of the FST in predicting AKI progression has not yet been fully discussed.

Methods: In accordance with Preferred Reporting Items for Systematic Reviews and Meta-Analyses (PRISMA) guidelines, we searched the PubMed, Embase, Cochrane databases up to March, 2020. The diagnostic performance of the FST (in terms of sensitivity, specificity, number of events, true positive, false positive) was extracted and evaluated.

Results: We identified eleven trials that enrolled a total of 1366 patients, including 517 patients and 1017 patients for whom the outcomes in terms of AKI stage progression and renal replacement therapy (RRT), respectively, were reported. The pooled sensitivity and specificity results of the FST for AKI progression prediction were 0.81 (95\% Cl: $0.74-0.87$ ) and 0.88 (95\% Cl: 0.82- 0.92), respectively. The pooled positive likelihood ratio (LR) was 5.45 (95\% Cl: 3.96-7.50), the pooled negative LR was 0.26 (95\% Cl: 0.19-0.36), and the pooled diagnostic odds ratio (DOR) was 29.69 (95\% Cl: 17.00-51.85). The summary receiver operating characteristics (SROC) with pooled diagnostic accuracy was 0.88 . The diagnostic performance of the FST in predicting AKI progression was not affected by different AKI criteria or underlying chronic kidney disease. The pooled sensitivity and specificity results of the FST for RRT prediction were 0.84 (95\% Cl: 0.72-0.91) and 0.77 (95\% Cl: 0.64-0.87), respectively. The pooled positive LR and pooled negative LR were 3.16 (95\% Cl: 2.06-4.86) and 0.25 (95\% Cl: 0.14-0.44), respectively. The pooled diagnostic odds ratio (DOR) was 13.59 (95\% Cl: 5.74-32.17) and SROC with pooled diagnostic accuracy was 0.86. The diagnostic performance of FST for RRT prediction is better in stage 1-2 AKI comparing to stage $3 \mathrm{AKI}$ (relative DOR: 5.75, 95\% Cl: 2.51-13.33)

Conclusion: The FST is a simple tool for the identification of AKI populations at high risk of AKI progression and the need for RRT and the diagnostic performance of FST in RRT prediction is better in early AKI population.

\section{Introduction}

The incidence of in-hospital acute kidney injury (AKI), depending on the different AKI criteria used, ranges from 7.0$18.3 \%$ [1] among hospitalized patients in general and up to $20-50 \%$ in critically ill populations [2]. The progression of AKI with multiple organ failure can result in poor prognosis. Because of the high morbidities and mortalities associated with AKI, many investigators have focused on several novel biomarkers for earlier detection of AKI, discrimination of etiologies, and prediction of outcomes [3-7]. However, the availability of these novel biomarkers may be limited by its expense or reimbursement issues in different countries. In addition to the therapeutic role of furosemide on fluid balance, blood pressure control, and the management of hypercalcemia, Chawla et al. proposed furosemide stress test (FST) as a tool for predicting AKI progression [8]. Several following studies also utilized FST to predict AKI progression or RRT prediction, but with heterogeneity in AKI criteria, cut-off value of urine output, duration of monitor or study designs. A few recent studies used FST to predict delayed graft function after kidney transplant $[9,10]$, and others focused on child populations [11, 12]. As such, in order to more effectively explore the diagnostic accuracy of the FST to predict AKI progression and RRT initiation, we conducted this meta-analysis according to the Preferred Reporting Items for Systematic Reviews and Meta-Analyses (PRISMA) diagnostic test accuracy guidelines [13].

\section{Methods}




\section{Literature Search}

In accordance with the PRISMA guidelines, two investigators (JJ-C, G-K) systematically and independently conducted a review of the relevant published data. A computerized search of the Pubmed, Embase, and Cochrane electronic databases was performed using the keywords "furosemide," "acute kidney injury," "acute kidney failure," and "renal insufficiency," and medical subject heading (MeSH) terms "Furosemide" [Mesh], "renal insufficiency"

[Mesh] AND "Acute Kidney Injury" [Mesh] in order to identify all the relevant studies up to March 2020. Review articles or meta-analyses were not included for analysis, but their citations and references were searched for additional relevant studies. The detail results of literature search were provided in Additional profile 1: Supplementary Table 1A \& 1B. We also performed search of grey literature and the detail is provided in Additional profile 2: Supplementary Document.

\section{Study Selection}

After the initial screening, the two investigators Jia Jin Chen (JJ-C) and George Kuo (G-K) independently determined the eligibility of the identified studies based on evaluations of their titles, abstracts, and, subsequently, full texts. Any differences in opinion regarding eligibility was resolved by consensus through discussion with Chih-Hsiang Chang. The full text of any article that was deemed potentially relevant was retrieved online. A study was included if it met the criteria of adult humans as its population, and reported the protocol and cut-off point of the FST. We enrolled studies with primary or secondary outcomes reporting the diagnostic value of the FST for AKI progression, RRT, or mortality. Studies were excluded if they met one or more of the following criteria: (1) focused on a population with solid organ or hematopoietic stem cell transplantation, (2) used duplicate cohorts, (3) contained insufficient information for analysis, (4) pediatric patients, or (5) did not report outcome of interest. Detailed results regarding excluded studies and the reasons for their exclusion are available in Additional profile 1: Supplementary Table 2. We have registered our work in PROSPERO. However, till we finished our work, the registration was still under assessed by the editorial team of PROSPERO; therefore, we provided our initial registered protocol as Additional profile 3.

\section{Data Extraction}

The two investigators independently extracted relevant information from each study. The extracted data elements included the first author, year of publication, study location, study design, diagnostic criteria of AKI, total sample size, protocol of the FST (that is, furosemide dose, duration of monitor, cut-off value of urine output), patients' AKI stages, outcomes of interest, whether or not the enrolled population had high plasma neutrophil gelatinase-associated lipocalin (NGAL) levels, and whether patients with chronic kidney disease were excluded or not (Table 1). As for diagnostic test performance, the extracted data included the cut-off value of urine output based on the Youden index or pre-defined criteria, sensitivity, specificity, number of true positive, number of false positive and the event number of AKI progression, RRT or mortality (Table 1 and Table 2).

\section{Outcome Measures}


The diagnostic criteria for AKI were different in the eleven enrolled studies. Five of the studies (Elsaegh, 2018; Lumlertgul, 2018; Martínez, 2016; Matsuura, 2018; Vairakkani, 2019) [14-18] used the Kidney Disease: Improving Global Outcomes (KDIGO) criteria [19]. Other studies used the Acute Kidney Injury Network (AKIN) criteria [20]. The reference test used in each study was based on the different AKI criteria in each trial or on whether the patients received RRT or mortality during follow up period. Four studies (Chawla, 2013; Pérez-Cruz, 2017; Rewa, 2019; Venugopal, 2019) [8, 21-23] used the AKIN stage 3 AKI as primary outcome. Three studies (Martínez, 2016; Matsuura, 2018; Vairakkani, 2019) [16-18] used the KDIGO stage 3 AKI as primary outcome. Two studies (Elsaegh, 2018; Saber, 2018) reported primary composite outcome consist of AKI progression and RRT [14, 24]. Six studies (Martínez, 2016; Lumlertgul, 2018; Matsuura, 2018; Pérez-Cruz, 2017; Sakhuja, 2019; Venugopal, 2019) reported outcome of RRT and two studies (Martínez, 2016; Venugopal, 2019) reported outcome of mortality [15-17, 21, 23, 25] (Table 2). Most studies reporting outcome of RRT did not mention the indications of renal replacement therapy except one (Lumlertgul, 2018) [15]. In this study, patient received RRT within 6 hours after randomization in early group or received RRT based on conventional indications in standard group.

\section{Risk of Bias Assessment}

The risk of bias for each of the included studies was assessed using the Quality Assessment of Diagnostic Accuracy Studies 2 (QUADAS-2) tool and Review Manager version 5.3 to identify the quality of the included studies [26]. The QUADAS-2 tool is based on four domains (patient selection, index test, reference standard, and flow and timing), which are used to judge the risk of bias. Each study was reviewed independently by JJ-C and G-K, with each investigator assigning a rating of high, low, or unclear risk for all four domains. The judgment principle of "applicability" was the same as the bias section, but there were no signaling questions. Disagreements between the reviewers were resolved by discussion with another author, Chih-Hsiang Chang. If the answer to all the signaling questions for a given domain was "yes," then the domain was considered to entail a low risk of bias. If the answer to any of the signaling questions for a domain was "no," then the domain was considered to entail a high risk of bias. The quality of evidence for the diagnostic performance of the FST in this meta-analysis was assessed based on the guidelines of the GRADE Working Group methodology [27]. We summarized the results in a table, which was constructed using the online GRADE Profiler (see Additional profile 4).

\section{Statistical Analysis}

We extracted the event number, total sample size, and true positive (TP), true negative (TN), false positive (FP), and false negative (FN) rates for each study or calculated these values according to the reported sensitivity and specificity. Based on these data, the positive likelihood ratio (+LR), negative likelihood ratio (-LR), and diagnostic odds ratio (DOR) could be obtained for each study. The summary measures were calculated using a bivariate model for the pooled sensitivity and specificity. We used a random-effect model with maximum likelihood estimation to calculate the pooled DOR and LR. The above two tests were conducted by the 'metabin' function in the 'meta' package [28]. To assess the diagnostic performance of the FST regarding AKI progression for FST non-responders, a summary receiver operating characteristics (SROC) curve was constructed by the 'restima' function with restricted maximum likelihood estimation in the 'mada' package [29]. The threshold effect was examined by using the Spearman correlation coefficient between the logit of sensitivity and logit of " 1 - specificity," and $P<0.05$ indicated the existence of a threshold effect. If there is no significant threshold effect, subgroup analysis or meta-regression 
analysis is warranted to clarify the sources of heterogeneity [30]. Heterogeneity from covariates other than the threshold effect among studies was evaluated using the $R$ index, with $R<25 \%, 25 \%-50 \%$, and $>50 \%$ indicating mild, moderate, and high heterogeneity, respectively. The LRs indicate whether the accuracy of a particular test would be more accurate for patients with a disease than for subjects without the disease. Several relevant variables were identified, and these variables are summarized in Table 1, Table 2 and Additional profile 1: Supplementary Table 3 (with the specific variables including the diagnostic criteria of AKI, whether the enrolled patients had high plasma NGAL, whether or not the enrolled patients had a clinical diagnosis of AKI, the use of a pre-specified cut-off value of urine output, the used FST protocol, prospective or retrospective study design, and whether the patients with chronic kidney disease were excluded). To explore possible sources of heterogeneity, these variables were applied as moderators in meta-regression weighted by the inverse of the study variance. We performed the metaregression by using 'metareg' function in the 'meta" package. A sensitivity analysis was performed after excluding studies using a composite outcome consist of AKI progression and RRT. All analyses were conducted using R version 3.6.2 (2019-12-12) [31]. A two-sided $P$ value of $<0.05$ was considered statistically significant.

\section{Results}

\section{Literature Search}

The initial search retrieved 1,902 records. After excluding duplicate articles, the remaining 1,679 articles were screened based on their titles and abstracts in order to identify the potentially relevant articles, the full texts of which then were downloaded and reviewed to further determine their eligibility for inclusion in the final analysis. Of the 29

articles, two [32,33] was suspected of using a duplicate cohort from another study [8], five were focused on child populations [11, 12, 34-36], and three were based on kidney transplant outcomes [9, 10, 37]. Meanwhile, five studies reported different outcomes of interest and the remaining three did not report sufficient information for analysis [3845] (Additional profile 1: Supplementary Table 2). As such, eleven studies were ultimately included in this metaanalytic study (Figure 1).

\section{Study Characteristics}

The eleven included trials enrolled a total of 1,366 patients with clinical AKI or a risk of AKI. Among those patients, 517 patients and 1,017 patients, respectively, had reported outcomes of AKI progression (including the need for RRT) or RRT. Most of the enrolled studies used prospective cohorts and four of then used non-prospective study designs or insufficient information about study designs (Chawla, 2013; Matsuura, 2018; Sakhuja, 2019; Vairakkani, 2019) $[8,17,18,25]$. All of the studies, except the two by Matsuura et al. and Sakhuja et al., used a standard furosemide dose, which is $1 \mathrm{mg} / \mathrm{kg}$ for the furosemide naive patients and $1.5 \mathrm{mg} / \mathrm{kg}$ for those patients exposed to furosemide within 7 days prior to FST $[17,25]$. Matsuura et al. used a complex cut-off value, which presented as urine volume divided by the administered furosemide dose (specifically, $3.9 \mathrm{ml}$ of urine output 2 hours after per mg furosemide administration) [17]. In the study by Sakhuja et al., the used dose of furosemide was at least $1 \mathrm{mg} / \mathrm{kg}$ [25]. Most of the studies used a 2-hour time interval to determine the FST responsiveness; only one study (Saber, 2018) used a 6-hour time interval [24]. Most studies used 200ml urine output within 2 hours after furosemide stress test as cut-off value except four studies (Matsuura, 2018; Saber, 2018; Sakhuja, 2019; Vairakkani, 2019) [17, 18, 24, 25] (Table 1). Three studies enrolled populations with high plasma NGAL levels (Chawla, 2013; Lumlertgul, 2018; Matsuura, 2018) $[8,15,17]$. Most studies did not report serum albumin level, which might be an important factor for diuresis response after furosemide administration. Only two studies reported serum albumin level (Matsuura, 2018 
average serum albumin: $2.8 \mathrm{~g} / \mathrm{dL}$ and Sakhuja, 2019 average serum albumin level: $2.9 \mathrm{~g} / \mathrm{dL})$ [17, 25]. Besides, the study by Lumlertgul et al. excluded patients with serum albumin level less than $2 \mathrm{~g} / \mathrm{dL}$ [15] (Additional profile 1: Supplementary Table 3).

\section{Risk of Bias}

With the QUADAS-2 tool, study characteristics or designs that might increase the risk of bias were identified. Domain 1 of the QUADAS-2 tool focuses on patient selection. One study (Elsaegh, 2018) [14] enrolled septic ICU patients with normal renal function and we considered this to entail a high risk of applicability concern. Another study (Matsuura, 2018) [17] enrolled patients with clinical AKI or subclinical AKI (that is, those with high biomarker levels that still did not meet the clinical AKI criteria). Two trials (Vairakkani, 2019; Venugopal, 2019) [18, 23] provided insufficient information about their study designs; therefore, the domain 1 aspects of the study populations for these two studies were considered to entail unclear risks. Domain 2 of the QUADAS-2 tool addresses the aspect of index tests. Six trials (Chawla, 2013; Matsuura, 2018; Rewa, 2019; Saber, 2018; Sakhuja, 2019; Vairakkani, 2019) [8, 17, 18, 22, $24,25]$ selected the urine output threshold to optimize sensitivity and/or specificity; therefore, these six studies were considered to have a high risk of bias regarding domain 2. All of the studies that used the AKIN or KDIGO AKI criteria or RRT as reference standard was considered to have low risk of bias. Four studies (Elsaegh, 2018; Pérez-Cruz, 2017; Saber, 2018; Venugopal, 2019) [14, 21, 23, 24] did not report a follow-up period for the primary or secondary outcomes. Therefore, these four studies were considered to have unclear risk of bias regarding domain 4 . Because of the reasons mentioned above, we considered one study (Elsaegh, 2018) [14] to have high applicability concern regarding patient selection and another one (Matsuura, 2018) [17] to have unclear concern. The other two domains of applicability concern in the included studies were all rated as low risk. We conducted the risk of bias analysis for all the included studies using Review Manager (RevMan) Version 5.3 [46], and the results are summarized in Figure 2.

\section{Furosemide Stress Test for Acute Kidney Injury Stage Progression Prediction}

The diagnostic values, cut-offs, and key results are summarized in Table 2 . The pooled sensitivity and specificity values were 0.81 (95\% Cl: 0.74-0.87) and 0.88 (95\% Cl: 0.82-0.92), respectively. The pooled positive LR was 5.45 (95\% Cl: 3.96-7.50), and the negative LR was 0.26 (95\% Cl: 0.19-0.36) (Figure 3). The heterogeneity of the aforementioned four pooled indices ranged from low to moderate ( $R$ ranged from 0.0-42\%) (Figure 3 ). The pooled DOR was 29.69 (95\% Cl: 17.00-51.85), with low heterogeneity $(R=0)$ (Supplementary Figure 1). The area under the curve (AUC) for SROC to summarize diagnostic accuracy was 0.88 (Supplementary Figure 2).

\section{Furosemide Stress Test for Renal Replacement Therapy Prediction}

Six studies reported the diagnostic value of FST in predicting RRT in AKI populations. Four studies (Lumlertgul, 2018; Martínez, 2016; Pérez-Cruz, 2017; Venugopal, 2019) used FST protocol identical to that used by Chawla et al. (1 $\mathrm{mg} / \mathrm{kg}$ for the furosemide naive patients or $1.5 \mathrm{mg} / \mathrm{kg}$ for patients who have exposure to furosemide and $200 \mathrm{ml}$ urine output after furosemide administration as cut-off value) $[8,15,16,21,23]$. One study (Matsuura, 2018) used complex cut-off value as above mentioned [17]. In one retrospective study (Sakhuja, 2019) [25], patient received at 
least $1 \mathrm{mg} / \mathrm{kg}$ furosemide and the cut-off value of urine output was $600 \mathrm{ml}$ at 6 hours after FST (Table 1). The pooled sensitivity and specificity values were 0.84 (95\% Cl: 0.72-0.91) and 0.77 (95\% Cl: 0.64-0.87), respectively. The pooled positive LR was 3.16 (95\% Cl:2.06-4.86), and the negative LR was 0.25 (95\% Cl: 0.14-0.44). The heterogeneity of the aforementioned four pooled indices was high ( $R$ ranged from 55-83\%) (Figure 4 ). The pooled DOR was 13.59 (95\% Cl: 5.74-32.17), with high heterogeneity ( $R=76 \%$ ) (Supplementary Figure 3 ). The area under the curve (AUC) for SROC to summarize diagnostic accuracy was 0.86 (Supplementary Figure 4 ).

\section{Furosemide Stress Test for Mortality Prediction}

Two studies (Martínez, 2016; Venugopal, 2019) reported the diagnostic value of FST for predicting mortality [16, 23]. Martínez et. al reported the prediction ability of FST for 30-day mortality. The follow up period was unclear in the study by Venugopal et al. The pooled sensitivity and specificity values were 0.48 (95\% Cl: $0.18-0.79)$ and 0.78 (95\% Cl: 0.67-0.86), respectively. The pooled positive LR was 2.64 (95\% Cl: 1.39-5.03), and the negative LR was 0.83 (95\% $\mathrm{Cl}$ : 0.53-1.29) (Supplementary Figure 5). The heterogeneity of the aforementioned four pooled indices was low to high ( $P$ ranged from 0-58\%). The pooled DOR was 4.09 (95\% Cl: 1.11-15.12), with moderate heterogeneity $\left(R^{2}=38 \%\right)$ (Supplementary Figure 6). The area under the curve (AUC) for SROC to summarize diagnostic accuracy was 0.78 (Supplementary Figure 7).

\section{Subgroup Analysis and Sensitivity Analysis}

To explore the source of heterogeneity, we perform subgroup analysis in regards to the diagnostic criteria of AKI, prospective or non-prospective design, use a pre-specified cut-off value of urine output, enrolled high NGAL population, different FST protocols, exclusion or inclusion of patients with baseline CKD and whether the primary outcome was a pure outcome. The analysis of threshold effect was performed with Spearman rank correlations ( $\rho=$ 0.197; $P=0.62$ ). The results implied that there was no significant threshold effect and subgroup analysis was required. The diagnostic performance of FST for AKI progression was not affected by different diagnostic criteria of AKI, exclusion or inclusion of CKD, different duration to monitor urine output, different FST protocol or the purity of primary outcome. The results of the subgroup analysis and sensitivity analysis are summarized and presented in Table 3.

There were 2 studies that provided a composite outcome consisting of diagnostic performance of FST for AKI progression and RRT prediction (Elsaegh, 2018; Saber, 2018) [14, 24]. A sensitivity analysis was conducted after excluding these two trials. The pooled sensitivity and specificity values of the remaining 7 studies were 0.79 ( $95 \% \mathrm{Cl}$ : 0.71-0.85) and 0.88 (95\% Cl: 0.83-0.91), respectively. The pooled positive LR was 6.07 (95\% Cl: 4.45-8.29), and the negative LR was 0.27 (95\% Cl: 0.20-0.38) (Supplementary Figure 8). The pooled DOR was 30.26 (95\% Cl: 16.6754.94) (Supplementary Figure 9). The SROC with pooled diagnostic accuracy was 0.90 (Supplementary Figure 10).

We also performed Spearman rank correlations ( $\rho=0.579 ; P=0.23)$ and then subgroup analysis for FST as an RRT prediction tool. The RRT incidence are different in enrolled studies (from 15.6\% in the study by Matsuura et al. to $66.6 \%$ in the study by Lumlertgul et al.). These six studies are also with variable follow up period (from 1 days to 30 days) and enrolled patients of different AKI severity (stage 1-2 or stage 3). Subgroup analysis showed that the diagnostic performance was not affected by study population with different RRT incidences (RRT incidence $<20 \%$ vs. $\geq 20 \%$; the relative diagnostic odd ratio: 1.19 with $95 \% \mathrm{Cl}$ : $0.37-3.78$ ) or different follow up durations (follow up 
duration not reported or $<7$ days vs. $\geq 7$ days; the relative diagnostic odd ratio: 3.71 with $95 \% \mathrm{Cl}: 0.80-71.11$ ). However, the diagnostic performance was better in early AKI stage population (stage 1-2) than in stage 3 (relative diagnostic odd ratio: 5.75 with 95\% Cl: 2.51 - 13.33) (Table 4).

\section{Discussion}

Furosemide has been used for decades. Its pharmacodynamics, pharmacokinetics, and adverse effects are well described in patients with chronic kidney disease or nephrotic syndrome, but less data is available regarding its effects in AKI populations. Because of its low cost and availability, using diuretic response as a preserved renal functional marker has been proposed. In 1973, Beak et al. reported that the urinary free water excretion following intravenous furosemide administration could serve as a diagnostic tool for acute tubular necrosis (ATN) [38]. Pandit and colleagues found that, while on furosemide therapy, patients who had urine output less than 1200ml 1-day after coronary artery bypass graft surgery were more likely to experience AKI, with a specificity of $97.93 \%$ [39]. It has been no one until 2013, Chawla et al. proposed a standard FST protocol, in which diuretic naïve-patients receive $1 \mathrm{mg} / \mathrm{kg}$ of furosemide and patients who exposed to furosemide within 7 days received $1.5 \mathrm{mg} / \mathrm{kg}$ of furosemide [8]. They use $200 \mathrm{ml}$ urine output at 2 hours after furosemide administration to serve as a cut-off value. In subjects with normal renal function or mild $\mathrm{AKI}$, the infusion dose and creatinine clearance are major determinants of diuretic response $[47,48]$. After AKI, several tubular function alterations could affect diuretic response, including a decrease of $\mathrm{Na}-\mathrm{K}-\mathrm{Cl}$ cotransporter 2 expression, Na-K-ATPase redistribution [49], and organic acid transporter mis-targeting [50]. Therefore, the FST seems to provide a quick and easy method for the assessment of glomerular filtration and tubular damage. Despite this aforementioned role in diagnostics, furosemide is unlikely to reduce mortality or decrease the risk of RRT in AKI populations [51]. We thus performed this systematic review and meta-analysis to clarify the predictive value of the FST on AKI progression, the need for RRT, and in-hospital mortality. First, the analysis of the diagnostic accuracy of the FST for AKI progression yielded an AUROC of 0.88 , with pooled sensitivity and specificity values of 0.81 and 0.88 , respectively. Although there are no studies directly comparing the diagnostic accuracy of FST with other biomarkers, the AUROC of FST for AKI progression is not inferior to that of biomarkers, which ranged from 0.70 to 0.85 in previous reports $[3,52,53]$. The diagnostic performance of FST was not affected by whether the enrolled patients have high plasma NGAL or not. Koyner et al., by using the same cohort with Chawla et al., reported the AUROC of FST was higher than that of each biomarker alone. Compared to the overall cohort, the diagnostic accuracy of FST improved when patients with elevated biomarkers [32]. The aforementioned studies and our work imply that FST could serve as a simple risk triage tool combined with or without novel biomarker in early AKI patients.

Second, our work demonstrated that use of the FST as a tool for RRT prediction had an AUROC of 0.86, with high heterogeneity in regarding pooled diagnostic indices. The pooled specificity and positive LR values of the FST for RRT prediction were relatively low. The subgroup analysis showed that diagnostic performance is better in early AKI population. According to the study by Lumlertgul et al., 25\% of the FST non-responder eventually did not undergo RRT because these patients did not meet the conventional criteria to start RRT. Lumlertgul et al. also demonstrated that in FST non-responders, whether early or late RRT initiation did not affect short-term mortality or renal recovery [15]. On the other hand, the FST responders are less likely to receive RRT. Matsuura et al. showed that only $5.6 \%$ (2/36) FST responders underwent RRT, whereas up to $40 \%(6 / 15)$ of FST non-responders requires RRT [17]. The major problems of RRT prediction lies in the optimal time for RRT initiation. Recently, several randomized controlled trials regarding to the optimal timing of RRT initiation were published. The ELAIN trial enrolled KDIGO stage 2 AKI demonstrated that survival benefit from early initiation of RRT. This trial was criticized for its single center designs, the enrollment of post- surgery population and some patients with significant fluid overload [54]. The 
AKIKI trial enrolled ICU patients with KDIGO stage $3 \mathrm{AKI}$ and demonstrated no benefit with earlier RRT initiation in regards to 60-day mortality [55]. The IDEAL-ICU trial enrolled patients with septic shock who achieved a 'failure' stage of AKI by RIFLE criteria but without life-threatening conditions, and found that there was no survival benefit with 'early' RRT [56]. Despite these large trials, we still have no conclusive answers about the optimal timing to start RRT. A recent published meta-analysis demonstrated that early RRT may be beneficial for a shorter duration on mechanical ventilation. However, a watchful waiting strategy based on conventional indications for RRT initiation was generally safe in regards to all-cause mortality [57]. FST non-responsiveness alone might not be a good indicator for RRT initiation. We should also take clinical condition, patient's demand and residual renal capacity into consideration as suggested by Acute Disease Quality Initiative XVII conference (ADQI) [58]. Overall, because of the inconsistency of timing of RRT initiation, FST non-responsiveness is not a good predictor for RRT; nevertheless, FST responsiveness might serve as a negative predictor for RRT, especially in early AKI stage.

Our study had several limitations. First, the risks of bias in the investigated studies were not low because of the existence of non-prospective study design, inconsistent diagnostic cut-off values, and mixed patient populations. Second, the serum albumin level has been considered as a factor of diuretic resistance based on early experimental data [59], and recent studies have shown that the co-administration of albumin and loop diuretics might transiently increase urine water and sodium excretion $[60,61]$. However, we did not have information about the serum albumin level in most study and whether loop diuretics were co-administered with albumin in the enrolled studies. Third, the indications for RRT initiation were not precisely reported in most studies. Further prospective studies with standard RRT initiation protocol are needed for further evaluation the ability of FST for RRT prediction. Due to the lack of large prospective studies meeting our criteria for inclusion, the total number of enrolled patients was relatively small. Two completed but not published trial (NCT02730117, NCT04215419) and another ongoing trial (NCT 01275729) were identified in the process of systematic research. Further results from these larger clinical studies are required in the future for validation the diagnostic role of FST in AKI severity.

\section{Conclusion}

In conclusion, FST non-responsiveness has a good predictive ability for AKI progression. The diagnostic performance of FST for RRT prediction is suboptimal and is better in early AKI population. Further trials with larger sample sizes with a high-quality study design are warranted to clarify the benefit of FST in clinical setting.

\section{List Of Abbreviations}

AKI: acute kidney injury

AKIN: Acute Kidney Injury Network

FST: furosemide stress test

KDIGO: Kidney Disease: Improving Global Outcomes

NGAL: neutrophil gelatinase-associated lipocalin

PC: prospective cohort

RC: retrospective cohort 


\section{Additional File Information}

Supplementary Figure 1. Diagnostic odd ratio of FST for prediction of AKI progression

Supplementary Figure 2. SROC curves of FST for prediction of AKI progression, SROC (summary receiver operating characteristic)

Supplementary Figure 3. Diagnostic odd ratio of FST for prediction of RRT

Supplementary Figure 4. SROC curves of FST for prediction of RRT

Supplementary Figure 5. Forest plot of FST diagnostic accuracy for mortality prediction

Supplementary Figure 6. Diagnostic odd ratio of FST for prediction of mortality

Supplementary Figure 7. SROC curves of FST for prediction of mortality

Supplementary Figure 8. Forest plot of FST diagnostic accuracy for AKI stage progression (exclusion of RRT)

Supplementary Figure 9. Diagnostic odd ratio of FST for prediction of AKI stage progression (exclusion of RRT)

Supplementary Figure 10. SROC curves of FST for prediction of AKI stage progression (exclusion of RRT)

\section{Additional profile}

Additional profile 1: Supplemental Tables

Additional profile 2: Supplemental Document

Additional profile 3: Registered PROSPERO review protocol

Additional Profile 4: GRADE Evidence and Summary of Findings Table

\section{Declarations}

Ethics approval and consent to participate: Not applicable

Consent for publication: Not applicable

Availability of data and materials: Not applicable

Competing interests: The authors declare that they have no competing interests

Funding: This research received no external funding

Author Contributions: Jia-Jin Chen, George Kuo : methodology and writing; Jia-Jin Chen , George Kuo, Yen Ta Huang: formal analysis; Jia-Jin Chen , George Kuo: data extraction; Jia-Jin Chen, writing-original draft preparation; ChihHsiang Chang : writing-review and editing; George Kuo : project administration. All authors read and approved the final manuscript. 


\section{References}

1. Zeng X, McMahon GM, Brunelli SM, Bates DW, Waikar SS. Incidence, outcomes, and comparisons across definitions of AKI in hospitalized individuals. Clin J Am Soc Nephrol. 2014;9(1):12-20.

2. Case J, Khan S, Khalid R, Khan A. Epidemiology of acute kidney injury in the intensive care unit. Crit Care Res Pract. 2013;2013:479730.

3. Klein SJ, Brandtner AK, Lehner GF, Ulmer H, Bagshaw SM, Wiedermann CJ, et al. Biomarkers for prediction of renal replacement therapy in acute kidney injury: a systematic review and meta-analysis. Intensive Care Med. 2018;44(3):323-36.

4. Zhang A, Cai Y, Wang PF, Qu JN, Luo ZC, Chen XD, et al. Diagnosis and prognosis of neutrophil gelatinaseassociated lipocalin for acute kidney injury with sepsis: a systematic review and meta-analysis. Crit Care. 2016;20:41.

5. Chang $\mathrm{CH}$, Yang $\mathrm{CH}$, Yang HY, Chen TH, Lin CY, Chang SW, et al. Urinary Biomarkers Improve the Diagnosis of Intrinsic Acute Kidney Injury in Coronary Care Units. Medicine (Baltimore). 2015;94(40):e1703.

6. Chen JJ, Fan PC, Kou G, Chang SW, Chen YT, Lee CC, et al. Meta-Analysis: Urinary Calprotectin for Discrimination of Intrinsic and Prerenal Acute Kidney Injury. J Clin Med. 2019;8(1).

7. Jia HM, Huang LF, Zheng Y, Li WX. Diagnostic value of urinary tissue inhibitor of metalloproteinase-2 and insulin-like growth factor binding protein 7 for acute kidney injury: a meta-analysis. Crit Care. 2017;21(1):77.

8. Chawla LS, Davison DL, Brasha-Mitchell E, Koyner JL, Arthur JM, Shaw AD, et al. Development and standardization of a furosemide stress test to predict the severity of acute kidney injury. Crit Care. 2013;17(5):R207.

9. McMahon BA, Koyner JL, Novick T, Menez S, Moran RA, Lonze BE, et al. The prognostic value of the furosemide stress test in predicting delayed graft function following deceased donor kidney transplantation. Biomarkers. 2018;23(1):61-9.

10. Udomkarnjananun S, Townamchai N, lampenkhae K, Petchlorlian A, Srisawat N, Katavetin P, et al. Furosemide Stress Test as a Predicting Biomarker for Delayed Graft Function in Kidney Transplantation. Nephron. 2019;141(4):236-48.

11. Borasino S, Wall KM, Crawford JH, Hock KM, Cleveland DC, Rahman F, et al. Furosemide Response Predicts Acute Kidney Injury After Cardiac Surgery in Infants and Neonates. Pediatr Crit Care Med. 2018;19(4):310-7.

12. Kakajiwala A, Kim JY, Hughes JZ, Costarino A, Ferguson J, Gaynor JW, et al. Lack of Furosemide Responsiveness Predicts Acute Kidney Injury in Infants After Cardiac Surgery. Ann Thorac Surg. 2017;104(4):1388-94.

13. Mclnnes MDF, Moher D, Thombs BD, McGrath TA, Bossuyt PM, and the P-DTAG, et al. Preferred Reporting Items for a Systematic Review and Meta-analysis of Diagnostic Test Accuracy Studies: The PRISMA-DTA Statement. JAMA. 2018;319(4):388-96.

14. Elsaegh HK NY, Elsayed HE, Elbasha AM. The role of furosemide stress test in the prediction of severity and outcome of sepsis-induced acute kidney injury. J Egypt Soc Nephrol Transplant 2018;18:86-95.

15. Lumlertgul N, Peerapornratana S, Trakarnvanich T, Pongsittisak W, Surasit K, Chuasuwan A, et al. Early versus standard initiation of renal replacement therapy in furosemide stress test non-responsive acute kidney injury patients (the FST trial). Crit Care. 2018;22(1):101.

Page $11 / 22$ 
16. Diana Vega Martínez GAÁ, Jonathan Samuel Chávez Iñiguez, Luis Enrique Colunga Lozano, Flavio César Estrada Gil. Precisión diagnóstica de prueba de estrés con furosemida para predicción de daño renal agudo severo. Rev Asoc Mex Med Crit Ter Int 2016;30(4):230-4.

17. Matsuura R, Komaru Y, Miyamoto Y, Yoshida T, Yoshimoto K, Isshiki R, et al. Response to different furosemide doses predicts AKI progression in ICU patients with elevated plasma NGAL levels. Ann Intensive Care. 2018;8(1):8.

18. R Vairakkani PAG, M Edwin Fernando, N D Srinivasa Prasad, S Sujit, K Thirumal Valavan, C Hariharan. Furosemide Stress Test to Predict the Severity of Acute Kidney Injury. Indian J Nephrol. 2019;29(Suppl S1):S24S5.

19. Section 2: AKI Definition. Kidney Int Suppl (2011). 2012;2(1):19-36.

20. Mehta RL, Kellum JA, Shah SV, Molitoris BA, Ronco C, Warnock DG, et al. Acute Kidney Injury Network: report of an initiative to improve outcomes in acute kidney injury. Crit Care. 2007;11(2):R31.

21. Elizabeth Pérez-Cruz AM-C, José Manuel Conde-Mercado,Eugenia Méndez-Calderillo. Comparación de la prueba de estrés con furosemida y biomarcadores séricos como predictores de la lesión renal aguda. Rev Hosp Jua Mex 2017;84(4):196-202.

22. Rewa OG, Bagshaw SM, Wang X, Wald R, Smith O, Shapiro J, et al. The furosemide stress test for prediction of worsening acute kidney injury in critically ill patients: A multicenter, prospective, observational study. J Crit Care. 2019;52:109-14.

23. L Venugopal RP, S Sreedhar, S Krishna Kumar, Arun Kumar Donakonda. Frusemide Stress Test to Predict Acute Kidney Injury Progression and Dialysis Requirement: A Prospective Study. Indian J Nephrol. 2019;29(Suppl S1):S46-S7.

24. Saber HM MW, Khaled H, Awad MA. Furosemide stress test, a novel assessment tool for tubular function in critically ill patients with acute kidney injury: potential therapeutic and prognostic values. Res Opin Anesth Intensive Care. 2019;6:273-81.

25. Sakhuja A, Bandak G, Barreto EF, Vallabhajosyula S, Jentzer J, Albright R, et al. Role of Loop Diuretic Challenge in Stage 3 Acute Kidney Injury. Mayo Clin Proc. 2019;94(8):1509-15.

26. Whiting PF, Rutjes AW, Westwood ME, Mallett S, Deeks JJ, Reitsma JB, et al. QUADAS-2: a revised tool for the quality assessment of diagnostic accuracy studies. Ann Intern Med. 2011;155(8):529-36.

27. GRADEpro GDT: GRADEpro Guideline Development Tool [Software]. McMaster University, 2015 (developed by Evidence Prime, Inc.). http://gradepro.org.

28. Balduzzi S, Rucker G, Schwarzer G. How to perform a meta-analysis with R: a practical tutorial. Evid Based Ment Health. 2019;22(4):153-60.

29. mada: Meta-Analysis of Diagnostic Accuracy. R package version 0.5.9. Philipp Doebler hCR-popm.

30. Arends LR, Hamza TH, van Houwelingen JC, Heijenbrok-Kal MH, Hunink MG, Stijnen T. Bivariate random effects meta-analysis of ROC curves. Med Decis Making. 2008;28(5):621-38.

31. R: A language and environment for statistical computing. R Foundation for Statistical Computing V, Austria. R Core Team (2019). https://www.R-project.org/.

32. Koyner JL, Davison DL, Brasha-Mitchell E, Chalikonda DM, Arthur JM, Shaw AD, et al. Furosemide Stress Test and Biomarkers for the Prediction of AKI Severity. J Am Soc Nephrol. 2015;26(8):2023-31.

33. THE FUROSEMIDE STRESS TEST IN COMBINATION WITH URINARY BIOMARKERS TO PREDICT THE PROGRESSION AND SEVERITY OF ACUTE KIDNEY INJURY. American Journal of Kidney Diseases. 
2014;63(5):B42.

34. Penk J, Gist KM, Wald EL, Kitzmiller L, Webb TN, Li Y, et al. Furosemide response predicts acute kidney injury in children after cardiac surgery. J Thorac Cardiovasc Surg. 2019;157(6):2444-51.

35. Vargas R, Cuevas J, Lopez E. [Furosemide in the early diagnosis of acute renal insufficiency in the newborn infant]. Bol Med Hosp Infant Mex. 1977;34(6):1317-30.

36. Kalra S SA, Narayan K, Gupta R. Use of furosemide stress test for edema control and predicting acute kidney injury in children with nephrotic syndrome. Indian Journal of Child Health. 2017;4(4):488-91.

37. Palma I SY, Kabagambe S, Perry A, Palma I, Sageshima J, Perez R. The Use of a Furosemide Stress Test (FST) for Assessment of Discarded Deceased Donor Kidneys in an Ex-Vivo Normothermic Perfusion Model. [abstract]. Am J Transplant. 2017;17(suppl 3).

38. Baek SM, Brown RS, Shoemaker WC. Early prediction of acute renal failure and recovery. II. Renal function response to furosemide. Ann Surg. 1973;178(5):605-8.

39. Amrita S. Pandit CP, FACS, Eugene Fernandes. Response to furosemide as marker of acute kidney injury in postoperative CABG patients. Journal of the American College of Surgeons. 2011;213(3):S46.

40. Rivero J, Rodriguez F, Soto V, Macedo E, Chawla LS, Mehta RL, et al. Furosemide stress test and interstitial fibrosis in kidney biopsies in chronic kidney disease. BMC Nephrol. 2020;21(1):87.

41. J. Kataoka YF, Y. Norisue, S. Fujitani. Does the response in urine output to a small dose of furosemide predict organ failure after achievement of negative fluid balance in acute respiratory failure? The interim analysis Intensive Care Medicine Experimental. 2017;5(Suppl 2):44.

42. van der Voort PH, Boerma EC, Pickkers P. The furosemide stress test to predict renal function after continuous renal replacement therapy. Crit Care. 2014;18(3):429.

43. Rivera SG SD, Beltrán MM, Peniche MKG, Gutiérrez JÁA, Calyeca SMV. Furosemide stress test to predict success or failure to remove continuos slow renal replacement therapy in acute renal injury. Rev Asoc Mex Med Crit y Ter Int. 2018;32(2):85-92.

44. Arkhipov VV, Papaian AV, Rivkin AM, Levicheva OV. [Functional furosemide loading test. Practical use in children with kidney diseases]. Klin Lab Diagn. 2001(3):20-4, 33.

45. Arifianto H. WT, Purwanto B. Acute kidney injury diagnosis in acute heart failure, does furosemide stress test make sense? European Heart Journal, Supplement 2017;19(Supplement E):E20-E1.

46. Review Manager (RevMan) [Computer program]. Version 5.3. Copenhagen: The Nordic Cochrane Centre, The Cochrane Collaboration, 2014.

47. Mariano F, Mella A, Vincenti M, Biancone L. Furosemide as a functional marker of acute kidney injury in ICU patients: a new role for an old drug. J Nephrol. 2019;32(6):883-93.

48. Chawla LS, Ronco C. Renal Stress Testing in the Assessment of Kidney Disease. Kidney Int Rep. 2016;1(1):5763.

49. Schmidt C, Hocherl K, Schweda F, Kurtz A, Bucher M. Regulation of renal sodium transporters during severe inflammation. J Am Soc Nephrol. 2007;18(4):1072-83.

50. Kunin M, Holtzman EJ, Melnikov S, Dinour D. Urinary organic anion transporter protein profiles in AKI. Nephrol Dial Transplant. 2012;27(4):1387-95.

51. Krzych LJ, Czempik PF. Impact of furosemide on mortality and the requirement for renal replacement therapy in acute kidney injury: a systematic review and meta-analysis of randomised trials. Ann Intensive Care.

2019;9(1):85.

Page $13 / 22$ 
52. Haase M, Bellomo R, Devarajan P, Schlattmann P, Haase-Fielitz A, Group NM-al. Accuracy of neutrophil gelatinase-associated lipocalin (NGAL) in diagnosis and prognosis in acute kidney injury: a systematic review and meta-analysis. Am J Kidney Dis. 2009;54(6):1012-24.

53. Greenberg JH, Zappitelli M, Jia Y, Thiessen-Philbrook HR, de Fontnouvelle CA, Wilson FP, et al. Biomarkers of AKI Progression after Pediatric Cardiac Surgery. J Am Soc Nephrol. 2018;29(5):1549-56.

54. Zarbock A, Kellum JA, Schmidt C, Van Aken H, Wempe C, Pavenstadt H, et al. Effect of Early vs Delayed Initiation of Renal Replacement Therapy on Mortality in Critically III Patients With Acute Kidney Injury: The ELAIN Randomized Clinical Trial. JAMA. 2016;315(20):2190-9.

55. Gaudry S, Hajage D, Schortgen F, Martin-Lefevre L, Pons B, Boulet E, et al. Initiation Strategies for RenalReplacement Therapy in the Intensive Care Unit. N Engl J Med. 2016;375(2):122-33.

56. Barbar SD, Clere-Jehl R, Bourredjem A, Hernu R, Montini F, Bruyere R, et al. Timing of Renal-Replacement Therapy in Patients with Acute Kidney Injury and Sepsis. N Engl J Med. 2018;379(15):1431-42.

57. Chen JJ, Lee CC, Kuo G, Fan PC, Lin CY, Chang SW, et al. Comparison between watchful waiting strategy and early initiation of renal replacement therapy in the critically ill acute kidney injury population: an updated systematic review and meta-analysis. Ann Intensive Care. 2020;10(1):30.

58. Ostermann M, Joannidis M, Pani A, Floris M, De Rosa S, Kellum JA, et al. Patient Selection and Timing of Continuous Renal Replacement Therapy. Blood Purif. 2016;42(3):224-37.

59. Inoue M, Okajima K, Itoh K, Ando Y, Watanabe N, Yasaka T, et al. Mechanism of furosemide resistance in analbuminemic rats and hypoalbuminemic patients. Kidney Int. 1987;32(2):198-203.

60. Phakdeekitcharoen B, Boonyawat K. The added-up albumin enhances the diuretic effect of furosemide in patients with hypoalbuminemic chronic kidney disease: a randomized controlled study. BMC Nephrol.

2012;13:92.

61. Kitsios GD, Mascari P, Ettunsi R, Gray AW. Co-administration of furosemide with albumin for overcoming diuretic resistance in patients with hypoalbuminemia: a meta-analysis. J Crit Care. 2014;29(2):253-9.

\section{Tables}

Table 1. The characteristics of the eleven included studies 


\begin{tabular}{|c|c|c|c|c|c|c|c|c|c|c|c|}
\hline $\begin{array}{c}\text { First } \\
\text { author/ } \\
\text { year }\end{array}$ & Location & Design & $\begin{array}{c}\text { AKI } \\
\text { criteria }\end{array}$ & Population & $\begin{array}{c}\text { Sample } \\
\text { size }\end{array}$ & $\begin{array}{l}\text { Furosemide } \\
\text { dose }\end{array}$ & $\begin{array}{c}\text { Urine } \\
\text { output } \\
\text { cutoff } \\
\text { point }\end{array}$ & $\begin{array}{c}\text { Outcome of } \\
\text { interest }\end{array}$ & $\begin{array}{l}\text { Enrolled } \\
\text { patients } \\
\text { AKI } \\
\text { stage }\end{array}$ & $\begin{array}{l}\text { High } \\
\text { plasma } \\
\text { NGAL }\end{array}$ & $\begin{array}{c}\text { Exclusion } \\
\text { of } \\
\text { chronic } \\
\text { kidney } \\
\text { disease } \\
\end{array}$ \\
\hline $\begin{array}{c}\text { Chawla, } \\
2013\end{array}$ & USA & $\begin{array}{l}\mathrm{PC}+ \\
\mathrm{RC}\end{array}$ & AKIN & Mixed & 77 & $\begin{array}{c}1 \mathrm{mg} / \mathrm{kg} \\
\text { (furosemide } \\
\text { naïve) or }\end{array}$ & $200 \mathrm{ml} / 2 \mathrm{hr}$ & $\begin{array}{c}\text { AKIN stage } \\
3\end{array}$ & $\begin{array}{c}\text { AKIN } \\
\text { stage 1- } \\
2\end{array}$ & Yes & $\begin{array}{c}\text { Yes } \\
(\text { eGFR< } \\
30)\end{array}$ \\
\hline $\begin{array}{l}\text { Elsaegh, } \\
2018\end{array}$ & Egypt & PC & KDIGO & Sepsis & 60 & $\begin{array}{c}1.5 \mathrm{mg} / \mathrm{kg} \\
\text { (furosemide } \\
\text { non-naïve) }\end{array}$ & & $\begin{array}{l}\text { KDIGO } \\
\text { stage } \\
\text { progression } \\
\text { (included } \\
\text { RRT) }\end{array}$ & $\begin{array}{l}\text { Normal } \\
\text { renal } \\
\text { function } \\
\& \text { any } \\
\text { stage of } \\
\text { AKI }\end{array}$ & No & Yes \\
\hline $\begin{array}{l}\text { Lumlertgul, } \\
2018\end{array}$ & Thailand & PC & KDIGO & Mixed & 162 & & & RRT & $\begin{array}{c}\text { Any } \\
\text { stage of } \\
\text { AKI }\end{array}$ & Yes & $\begin{array}{c}\text { Yes } \\
\text { (baseline } \\
\text { Cr }>2 \text { ) }\end{array}$ \\
\hline $\begin{array}{l}\text { Martínez, } \\
2016\end{array}$ & Mexico & PC & KDGO & NA & 20 & & & $\begin{array}{l}\text { KDIGO } \\
\text { stage-3 \& } \\
\text { RRT }\end{array}$ & $\begin{array}{l}\text { KDIGO } \\
\text { stage 1- } \\
2\end{array}$ & No & $\begin{array}{c}\text { Yes } \\
(\text { eGFR }< \\
30)\end{array}$ \\
\hline $\begin{array}{l}\text { Matsuura, } \\
2018\end{array}$ & Japan & $\mathrm{RC}$ & KDIGO & Mixed & 51 & NA & $\begin{array}{c}3.9 \mathrm{ml} / 2 \mathrm{hr} \\
\text { for per mg } \\
\text { furosemide }\end{array}$ & $\begin{array}{c}\text { KDIGO } \\
\text { stage } 3 \& \\
\text { RRT }\end{array}$ & $\begin{array}{l}\text { KDIGO } \\
\text { stage 1- } \\
2 \text { or } \\
\text { high } \\
\text { NGAL } \\
\text { with } \\
\text { normal } \\
\text { renal } \\
\text { function }\end{array}$ & Yes & No \\
\hline $\begin{array}{c}\text { Pérez- } \\
\text { Cruz, } 2017\end{array}$ & Mexico & PC & AKIN & Medical & 35 & $\begin{array}{c}1 \mathrm{mg} / \mathrm{kg} \\
\text { (furosemide } \\
\text { naïve) or }\end{array}$ & $200 \mathrm{ml} / 2 \mathrm{hr}$ & $\begin{array}{c}\text { AKIN-3 \& } \\
\text { RRT }\end{array}$ & $\begin{array}{c}\text { AKIN } \\
\text { stage 1- } \\
2\end{array}$ & No & No \\
\hline $\begin{array}{c}\text { Rewa, } \\
2019\end{array}$ & $\begin{array}{l}\text { USA and } \\
\text { Canada }\end{array}$ & PC & AKIN & Mixed & 92 & $\begin{array}{c}1.5 \mathrm{mg} / \mathrm{kg} \\
\text { (furosemide } \\
\text { non-naïve) }\end{array}$ & & $\begin{array}{c}\text { AKIN stage } \\
3\end{array}$ & $\begin{array}{c}\text { AKIN } \\
\text { stage 1- } \\
2\end{array}$ & No & $\begin{array}{c}\text { Yes } \\
(\text { eGFR< } \\
30)\end{array}$ \\
\hline $\begin{array}{c}\text { Saber, } \\
2018\end{array}$ & Egypt & PC & AKIN & NA & 40 & & $325 \mathrm{ml} / 6 \mathrm{hr}$ & $\begin{array}{l}\text { AKIN stage } \\
3 \text { (included } \\
\text { RRT) }\end{array}$ & $\begin{array}{c}\text { AKIN } \\
\text { stage 1- } \\
2\end{array}$ & No & $\begin{array}{c}\text { Yes } \\
(\text { eGFR< } \\
30)\end{array}$ \\
\hline $\begin{array}{c}\text { Sakhuja, } \\
2019\end{array}$ & USA & $\mathrm{RC}$ & AKIN & NA & 687 & $\geq 1 \mathrm{mg} / \mathrm{kg}$ & $600 \mathrm{ml} / 6 \mathrm{hr}$ & RRT & $\begin{array}{c}\text { AKIN } \\
\text { stage } 3\end{array}$ & No & No \\
\hline $\begin{array}{l}\text { Vairakkani, } \\
2019\end{array}$ & India & NA & KDIGO & NA & 80 & $\begin{array}{c}1 \mathrm{mg} / \mathrm{kg} \\
\text { (furosemide } \\
\text { naïve) or }\end{array}$ & $325 \mathrm{ml} / 2 \mathrm{hr}$ & $\begin{array}{l}\text { KDIGO } \\
\text { stage } 3\end{array}$ & $\begin{array}{l}\text { KDIGO } \\
\text { stage 1- } \\
2\end{array}$ & No & $\begin{array}{c}\text { Yes } \\
(\text { eGFR< } \\
30)\end{array}$ \\
\hline $\begin{array}{l}\text { Venugopal, } \\
2019\end{array}$ & India & PC & AKIN & NA & 62 & $\begin{array}{c}1.5 \mathrm{mg} / \mathrm{kg} \\
\text { (furosemide } \\
\text { non-naïve) }\end{array}$ & $200 \mathrm{ml} / 2 \mathrm{hr}$ & $\begin{array}{c}\text { AKIN-3 \& } \\
\text { RRT }\end{array}$ & $\begin{array}{c}\text { AKIN } \\
\text { stage 1- } \\
2\end{array}$ & No & No \\
\hline
\end{tabular}

Abbreviation: AKI (acute kidney injury), AKIN (Acute Kidney Injury Network), Cr (Creatinine), eGFR (estimated Glomerular filtration rate), KDIGO (Kidney Disease Global outcomes), NA (not applicable), PC (prospective cohort), RC (Retrospective cohort), RRT (Renal replacement therapy)

Table 2 Diagnostic test performance of furosemide stress test for AKI progression, renal replacement therapy and mortality 


\begin{tabular}{|c|c|c|c|c|c|c|c|c|c|}
\hline Study & Sensitivity & Specificity & $\begin{array}{c}\text { sample } \\
\text { size }\end{array}$ & $\begin{array}{c}\text { Event } \\
\text { (AKI } \\
\text { progression) } \\
\end{array}$ & TP & FP & FN & TN & $\begin{array}{l}\text { Follow up } \\
\text { period }\end{array}$ \\
\hline $\begin{array}{c}\text { Chawla, } 2013 \\
\text { Elsaegh, } 2018 \\
\text { Martínez, } 2016 \\
\text { Matsuura, } 2018 \\
\text { Pérez-Cruz, }\end{array}$ & $\begin{array}{l}87.1 \\
89.3 \\
66.7 \\
76.5 \\
57.1\end{array}$ & $\begin{array}{l}84.1 \\
93.4 \\
100 \\
94.1 \\
95.2\end{array}$ & $\begin{array}{l}77 \\
60 \\
20 \\
51 \\
35\end{array}$ & $\begin{array}{l}25 \\
28 \\
6 \\
17 \\
14\end{array}$ & $\begin{array}{c}22 \\
25 \\
5 \\
13 \\
8\end{array}$ & $\begin{array}{l}8 \\
2 \\
0 \\
2 \\
1\end{array}$ & $\begin{array}{l}3 \\
3 \\
2 \\
4 \\
6\end{array}$ & $\begin{array}{l}44 \\
30 \\
14 \\
32 \\
20\end{array}$ & $\begin{array}{l}14 \text { days } \\
\text { NA } \\
30 \text { days } \\
7 \text { days } \\
\text { NA }\end{array}$ \\
\hline $\begin{array}{l}\text { Saber, } 2018 \\
\text { Rewa, } 2019 \\
\text { Vairakkani, }\end{array}$ & $\begin{array}{c}86.7 \\
73.9 \\
82\end{array}$ & $\begin{array}{c}68 \\
90 \\
80.8\end{array}$ & $\begin{array}{l}40 \\
92 \\
80\end{array}$ & $\begin{array}{l}15 \\
23 \\
28\end{array}$ & $\begin{array}{l}13 \\
17 \\
23\end{array}$ & $\begin{array}{c}8 \\
7 \\
10\end{array}$ & $\begin{array}{l}2 \\
6 \\
5\end{array}$ & $\begin{array}{l}17 \\
62 \\
42\end{array}$ & $\begin{array}{c}\text { NA } \\
30 \text { days } \\
14 \text { days }\end{array}$ \\
\hline $\begin{array}{c}\text { Venugopal, } \\
2019\end{array}$ & 85.7 & 87.5 & 62 & 14 & 12 & 6 & 2 & 42 & NA \\
\hline Study & Sensitivity & Specificity & $\begin{array}{c}\text { sample } \\
\text { size }\end{array}$ & Event (RRT) & TP & FP & FN & TN & $\begin{array}{l}\text { Follow up } \\
\text { period }\end{array}$ \\
\hline $\begin{array}{l}\text { Lumlertgul, } \\
2018\end{array}$ & 94.4 & 70.4 & 162 & 108 & 102 & 16 & 6 & 38 & 28 days \\
\hline $\begin{array}{c}\text { Martínez, } 2016 \\
\text { Matsuura, } 2018 \\
\text { Pérez-Cruz, }\end{array}$ & $\begin{array}{c}75 \\
75 \\
62.5\end{array}$ & $\begin{array}{l}93.7 \\
79 \\
85.2\end{array}$ & $\begin{array}{l}20 \\
51 \\
35\end{array}$ & $\begin{array}{l}4 \\
8 \\
8\end{array}$ & $\begin{array}{l}3 \\
6 \\
5\end{array}$ & $\begin{array}{l}1 \\
9 \\
4\end{array}$ & $\begin{array}{l}1 \\
2 \\
3\end{array}$ & $\begin{array}{l}15 \\
34 \\
23\end{array}$ & $\begin{array}{l}30 \text { days } \\
7 \text { days } \\
\text { NA }\end{array}$ \\
\hline $\begin{array}{c}2017 \\
\text { Sakhuja, } 2019 \\
\text { Venugopal, } \\
2019\end{array}$ & $\begin{array}{l}80.9 \\
83.3\end{array}$ & $\begin{array}{l}50.5 \\
84\end{array}$ & $\begin{array}{c}687 \\
62\end{array}$ & $\begin{array}{c}162 \\
12\end{array}$ & $\begin{array}{c}131 \\
10\end{array}$ & $\begin{array}{c}260 \\
8\end{array}$ & $\begin{array}{c}31 \\
2\end{array}$ & $\begin{array}{l}265 \\
42\end{array}$ & $\begin{array}{c}1 \text { days } \\
\text { NA }\end{array}$ \\
\hline Study & Sensitivity & Specificity & $\begin{array}{c}\text { sample } \\
\text { size }\end{array}$ & Event (Mortality) & TP & FP & FN & TN & $\begin{array}{l}\text { Follow up } \\
\text { period }\end{array}$ \\
\hline $\begin{array}{c}\text { Martínez, } 2016 \\
\text { Venugopal, } \\
2019\end{array}$ & $\begin{array}{l}20 \\
66.7\end{array}$ & $\begin{array}{c}80 \\
77.3\end{array}$ & $\begin{array}{l}20 \\
62\end{array}$ & $\begin{array}{l}5 \\
9\end{array}$ & $\begin{array}{l}1 \\
6\end{array}$ & $\begin{array}{c}3 \\
12\end{array}$ & $\begin{array}{l}4 \\
3\end{array}$ & $\begin{array}{l}12 \\
41\end{array}$ & $\begin{array}{c}30 \text { days } \\
\text { NA }\end{array}$ \\
\hline
\end{tabular}

Abbreviation: AUROC (Area Under the Receiver Operating Characteristics), AKI (Acute kidney injury), FN (False negative), FP (False positive), NA (not applicable), RRT (Renal replacement therapy), TN (True negative), TP (True positive)

Table 3 Heterogeneity analysis of meta-analyses (outcome included sensitivity analysis and meta-regression) for furosemide stress test as an AKI progression prediction tool 


\begin{tabular}{|c|c|c|c|c|c|c|c|c|c|c|c|}
\hline riables & Subgroups & $\begin{array}{l}\text { Number of } \\
\text { studies }\end{array}$ & $\begin{array}{l}\text { Sensitivity } \\
(95 \% \mathrm{Cl})\end{array}$ & $\begin{array}{l}\text { Specificity } \\
(95 \% \mathrm{Cl})\end{array}$ & $\begin{array}{l}\text { Positive } \\
\text { LR } \\
(95 \% \mathrm{Cl})\end{array}$ & $\begin{array}{c}\text { Negative } \\
\text { LR }\end{array}$ & $\begin{array}{l}\text { Diagnostic odd } \\
\text { ratio }(95 \% \mathrm{Cl})\end{array}$ & Coeff. & SE & $\begin{array}{c}P \\
\text { value }\end{array}$ & $\begin{array}{l}\text { RDOR } \\
(95 \% \\
\mathrm{Cl})\end{array}$ \\
\hline & & & & & & $(95 \% \mathrm{Cl})$ & & & & & \\
\hline I criteria & AKIN & 5 & $\begin{array}{c}0.79 \\
(0.68- \\
0.87)\end{array}$ & $\begin{array}{c}0.86 \\
(0.79- \\
0.91)\end{array}$ & $\begin{array}{c}5.22 \\
(3.45- \\
7.89)\end{array}$ & $\begin{array}{c}0.28 \\
(0.19- \\
0.42)\end{array}$ & $\begin{array}{c}27.88 \\
(13.85-56.12)\end{array}$ & & & & \\
\hline & KDIGO & 4 & $\begin{array}{c}0.84 \\
(0.73- \\
0.92)\end{array}$ & $\begin{array}{c}0.91 \\
\\
(0.78- \\
0.97)\end{array}$ & $\begin{array}{c}5.66 \\
(3.51- \\
9.14)\end{array}$ & $\begin{array}{c}0.21 \\
(0.12- \\
0.37)\end{array}$ & $\begin{array}{c}33.11 \\
(13.15-83.42)\end{array}$ & 0.17 & 0.59 & 0.77 & $\begin{array}{c}1.19 \\
\\
(0.37 \\
- \\
3.78)\end{array}$ \\
\hline toff point time & $\begin{array}{l}6 \text { hours } \\
2 \text { hours }\end{array}$ & $\begin{array}{l}1 \\
8\end{array}$ & $\begin{array}{c}0.81 \\
(0.72- \\
0.87)\end{array}$ & $\begin{array}{c}0.89 \\
(0.84- \\
0.92)\end{array}$ & $\begin{array}{c}6.23 \\
(4.57- \\
8.49)\end{array}$ & $\begin{array}{c}0.27 \\
(0.19- \\
0.37)\end{array}$ & $\begin{array}{c}32.52 \\
(18.03-58.66)\end{array}$ & 0.86 & 0.92 & 0.35 & $\begin{array}{c}2.36 \\
\\
(0.38 \\
- \\
14.30)\end{array}$ \\
\hline ıdy design & $\begin{array}{c}\text { Non- } \\
\text { prospective }\end{array}$ & 3 & $\begin{array}{c}0.83 \\
(0.72- \\
0.90)\end{array}$ & $\begin{array}{c}0.86 \\
(0.79- \\
0.90)\end{array}$ & $\begin{array}{c}5.32 \\
(3.51- \\
8.05)\end{array}$ & $\begin{array}{c}0.21 \\
(0.12- \\
0.35)\end{array}$ & $\begin{array}{c}30.03 \\
(13.29-67.82)\end{array}$ & & & & \\
\hline & Prospective & 6 & $\begin{array}{c}0.82 \\
(0.66- \\
0.92)\end{array}$ & $\begin{array}{c}0.89 \\
(0.80- \\
0.95)\end{array}$ & $\begin{array}{c}5.70 \\
(3.50- \\
9.27)\end{array}$ & $\begin{array}{c}0.30 \\
\\
(0.20- \\
0.45)\end{array}$ & $\begin{array}{c}29.39 \\
(13.68-63.15)\end{array}$ & -0.02 & 0.57 & 0.97 & $\begin{array}{c}0.98 \\
\\
(0.31 \\
- \\
3.00)\end{array}$ \\
\hline y $\mathrm{h}$ NAL & No & 7 & $\begin{array}{c}0.81 \\
(0.70- \\
0.89)\end{array}$ & $\begin{array}{c}0.88 \\
(0.80- \\
0.94)\end{array}$ & $\begin{array}{c}5.14 \\
(3.54- \\
7.46)\end{array}$ & $\begin{array}{c}0.28 \\
(0.20- \\
0.41)\end{array}$ & $\begin{array}{c}25.99 \\
(13.66-49.44)\end{array}$ & & & & \\
\hline & Yes & 2 & $\begin{array}{l}0.83 \\
\\
(0.69 \\
0.92)\end{array}$ & $\begin{array}{c}0.88 \\
(0.80- \\
0.93)\end{array}$ & $\begin{array}{l}6.66 \\
(3.69- \\
12.01)\end{array}$ & $\begin{array}{c}0.20 \\
\\
(0.10- \\
0.39)\end{array}$ & $\begin{array}{c}44.42 \\
(14.50-136.10)\end{array}$ & 0.54 & 0.66 & 0.42 & $\begin{array}{c}1.71 \\
\\
(0.46 \\
- \\
6.23)\end{array}$ \\
\hline lusion of late CKD & No & 3 & $\begin{array}{c}0.73 \\
(0.59- \\
0.84)\end{array}$ & $\begin{array}{c}0.91 \\
(0.84- \\
0.95)\end{array}$ & $\begin{array}{l}8.37 \\
(4.41- \\
15.86)\end{array}$ & $\begin{array}{c}0.33 \\
\\
(0.21- \\
0.53)\end{array}$ & $\begin{array}{c}40.84 \\
(13.66-122.10)\end{array}$ & & & & \\
\hline & Yes & 6 & $\begin{array}{c}0.85 \\
(0.76- \\
0.90)\end{array}$ & $\begin{array}{c}0.86 \\
(0.78- \\
0.91)\end{array}$ & $\begin{array}{c}4.79 \\
(3.42- \\
6.71)\end{array}$ & $\begin{array}{c}0.21 \\
(0.14- \\
0.33)\end{array}$ & $\begin{array}{c}26.55 \\
(13.89-50.75)\end{array}$ & -0.43 & 0.65 & 0.51 & $\begin{array}{c}0.65 \\
\\
(0.18 \\
- \\
2.31)\end{array}$ \\
\hline T protocol & Others & 3 & $\begin{array}{c}0.82 \\
(0.70- \\
0.90)\end{array}$ & $\begin{array}{c}0.83 \\
(0.68- \\
0.92)\end{array}$ & $\begin{array}{c}3.85 \\
(2.57- \\
5.74)\end{array}$ & $\begin{array}{c}0.23 \\
\\
(0.13- \\
0.39)\end{array}$ & $\begin{array}{c}22.16 \\
(9.38-52.32)\end{array}$ & & & & \\
\hline & $\begin{array}{l}\text { Standard FST } \\
\text { protocol }\end{array}$ & 6 & $\begin{array}{c}0.83 \\
(0.68- \\
0.92)\end{array}$ & $\begin{array}{c}0.89 \\
(0.85- \\
0.93)\end{array}$ & $\begin{array}{c}6.90 \\
(4.72- \\
10.08)\end{array}$ & $\begin{array}{c}0.27 \\
\\
(0.17- \\
0.42)\end{array}$ & $\begin{array}{c}36.73 \\
(17.65-76.44)\end{array}$ & 0.51 & 0.58 & 0.38 & $\begin{array}{c}1.66 \\
\\
(0.53 \\
- \\
5.10)\end{array}$ \\
\hline $\begin{array}{l}\text { xed outcome of RRT \& } \\
\text { I progression }\end{array}$ & Yes & 2 & $\begin{array}{c}0.92 \\
(0.72- \\
0.98)\end{array}$ & $\begin{array}{c}0.94 \\
(0.20- \\
0.99)\end{array}$ & $\begin{array}{c}3.08 \\
(1.71- \\
5.56)\end{array}$ & $\begin{array}{c}0.15 \\
(0.05- \\
0.50)\end{array}$ & $\begin{array}{c}25.98 \\
(5.40-125.08)\end{array}$ & & & & \\
\hline & No & 7 & $\begin{array}{c}0.79 \\
(0.71- \\
0.85)\end{array}$ & $\begin{array}{c}0.88 \\
(0.83- \\
0.91)\end{array}$ & $\begin{array}{c}6.07 \\
(4.45- \\
8.29)\end{array}$ & $\begin{array}{c}0.27 \\
(0.20- \\
0.38)\end{array}$ & $\begin{array}{c}30.26 \\
(16.67-54.94)\end{array}$ & 0.15 & 0.86 & 0.86 & $\begin{array}{c}1.16 \\
\\
(0.22 \\
- \\
6.23)\end{array}$ \\
\hline
\end{tabular}

Page $17 / 22$ 
Abbreviation: AKI (Acute kidney injury), AKIN (Acute Kidney Injury Network), KDIGO (Kidney Disease Improving Global Outcomes), LR (likelihood ratio), NGAL (Neutrophil gelatinase-associated lipocalin), RDOR (Relative diagnostic odd ratio), SE (Standard error), UOP (urine output)

\# Standard FST protocol (dose $1 \mathrm{mg} / \mathrm{kg}$ for furosemide naïve or $1.5 \mathrm{mg} / \mathrm{kg}$ for furosemide non-naïve patients and urine output cut-off value: $200 \mathrm{ml}$ within 2 hours)

Table 4 Heterogeneity analysis of meta-analyses (outcome included sensitivity analysis and meta-regression) for furosemide stress test as a renal replacement therapy prediction tool

\begin{tabular}{|c|c|c|c|c|c|c|c|c|c|c|c|}
\hline riables & Subgroups & $\begin{array}{l}\text { Number of } \\
\text { studies }\end{array}$ & $\begin{array}{c}\text { Sensitivity } \\
(95 \% \mathrm{Cl})\end{array}$ & $\begin{array}{l}\text { Specificity } \\
(95 \% \mathrm{Cl})\end{array}$ & $\begin{array}{c}\text { Positive } \\
\text { LR } \\
(95 \% \mathrm{Cl})\end{array}$ & $\begin{array}{c}\text { Negative } \\
\text { LR } \\
(95 \% \mathrm{Cl})\end{array}$ & $\begin{array}{c}\text { Diagnostic odd ratio } \\
(95 \% \mathrm{Cl})\end{array}$ & Coeff. & SE & $\begin{array}{c}P \\
\text { value }\end{array}$ & $\begin{array}{l}\text { RDOR } \\
(95 \% \mathrm{Cl})\end{array}$ \\
\hline \multirow[t]{2}{*}{ Trate } & $<20 \%$ & 2 & $\begin{array}{c}0.80 \\
(0.57- \\
0.92)\end{array}$ & $\begin{array}{c}0.82 \\
\\
(0.73- \\
0.88)\end{array}$ & $\begin{array}{c}4.35 \\
(2.66- \\
7.10)\end{array}$ & $\begin{array}{c}0.25 \\
\\
(0.11- \\
0.61)\end{array}$ & $\begin{array}{c}17.52 \\
(5.16-59.44)\end{array}$ & & & & \\
\hline & $\geq 20 \%$ & 4 & $\begin{array}{c}0.85 \\
(0.69- \\
0.93)\end{array}$ & $\begin{array}{c}0.76 \\
(0.54- \\
0.89)\end{array}$ & $\begin{array}{c}2.64 \\
(1.62- \\
4.32)\end{array}$ & $\begin{array}{c}0.25 \\
(0.12- \\
0.51)\end{array}$ & $\begin{array}{c}12.81 \\
(4.19-39.12)\end{array}$ & 0.17 & 0.59 & 0.77 & $\begin{array}{c}1.19 \\
(0.37- \\
3.78)\end{array}$ \\
\hline \multirow[t]{2}{*}{ duration } & $\begin{array}{c}\text { Not report or }<7 \\
\text { days }\end{array}$ & 3 & $\begin{array}{c}0.80 \\
(0.74- \\
0.85)\end{array}$ & $\begin{array}{c}0.74 \\
\\
(0.52- \\
0.89)\end{array}$ & $\begin{array}{c}2.89 \\
(1.49- \\
5.57)\end{array}$ & $\begin{array}{c}0.37 \\
(0.28- \\
0.50)\end{array}$ & $\begin{array}{c}4.97 \\
(3.32-7.44)\end{array}$ & & & & \\
\hline & $\geq 7$ days & 3 & $\begin{array}{c}0.91 \\
(0.66- \\
0.98)\end{array}$ & $\begin{array}{c}0.77 \\
(0.65- \\
0.86)\end{array}$ & $\begin{array}{c}3.42 \\
(2.41- \\
4.86)\end{array}$ & $\begin{array}{c}0.15 \\
(0.07- \\
0.34)\end{array}$ & $\begin{array}{l}30.46 \\
\quad(13.13-70.66)\end{array}$ & 1.31 & 0.78 & 0.09 & $\begin{array}{c}3.71 \\
(0.80- \\
71.11)\end{array}$ \\
\hline \multirow{3}{*}{$\begin{array}{l}\text { I } \\
\text { Ige } \\
\text { olled }\end{array}$} & Stage 3 & 1 & & & & & & & & & \\
\hline & & & & & & & & & & & \\
\hline & Stage 1 or 2 & 5 & $\begin{array}{c}0.85 \\
(0.68- \\
0.94)\end{array}$ & $\begin{array}{c}0.80 \\
(0.73- \\
0.86)\end{array}$ & $\begin{array}{c}3.77 \\
(2.80- \\
5.09)\end{array}$ & $\begin{array}{c}0.21 \\
(0.11- \\
0.41)\end{array}$ & $\begin{array}{c}24.93 \\
(12.45-49.91)\end{array}$ & 1.75 & 0.43 & $<0.01$ & $\begin{array}{c}5.75 \\
(2.51- \\
13.33)\end{array}$ \\
\hline
\end{tabular}

Abbreviation: AKI (Acute kidney injury), LR (likelihood ratio), RDOR (Relative diagnostic odd ratio), RRT (Renal replacement therapy), SE (Standard error), UOP (urine output)

\section{Figures}


PRISMA 2009 Flow Diagram
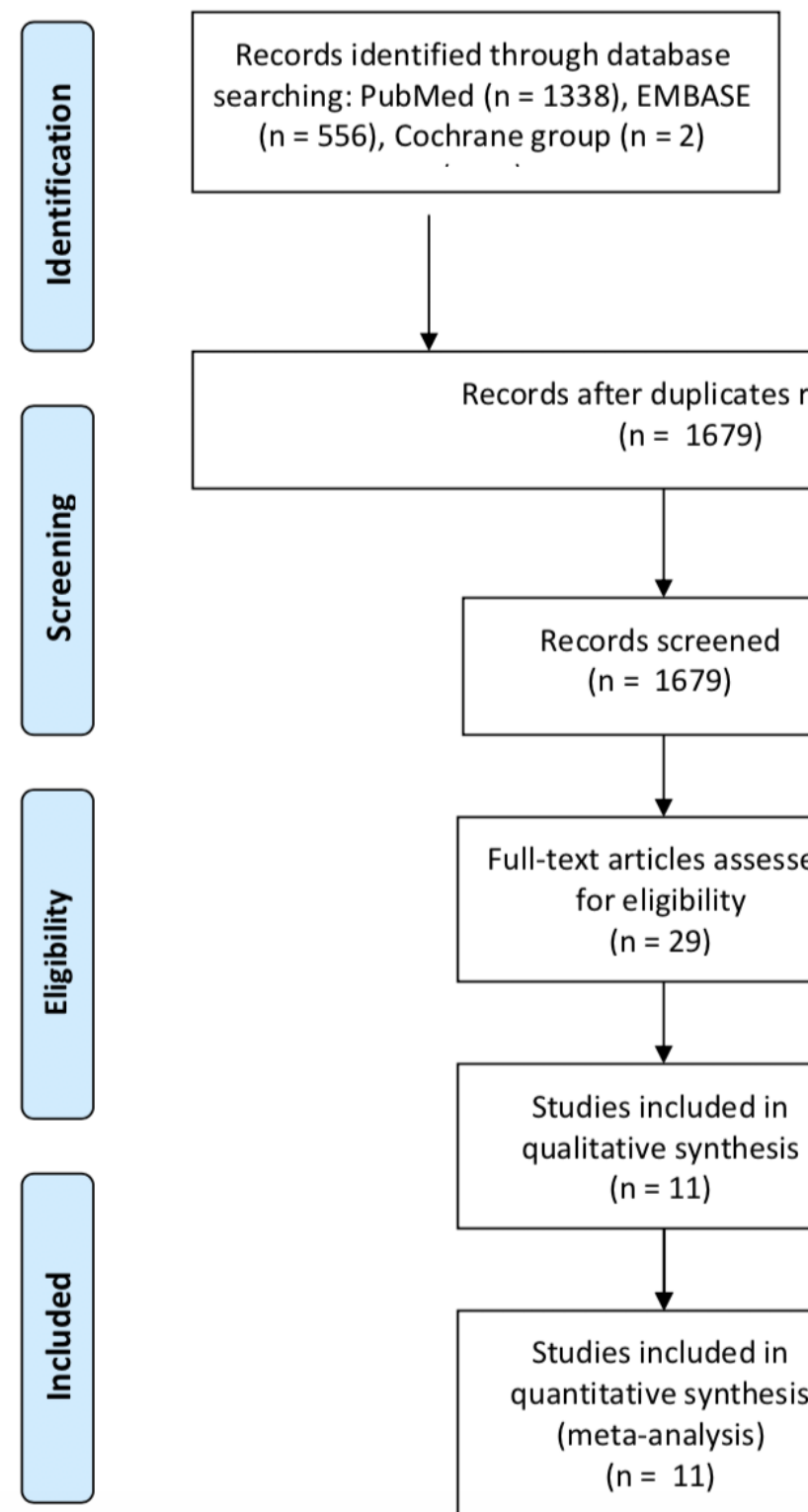

Additional research identified through

other sources: $(n=6)$

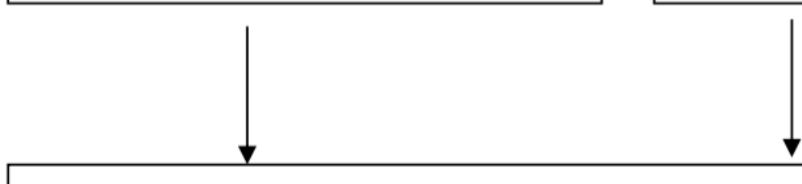

Records after duplicates removed

$(n=1679)$

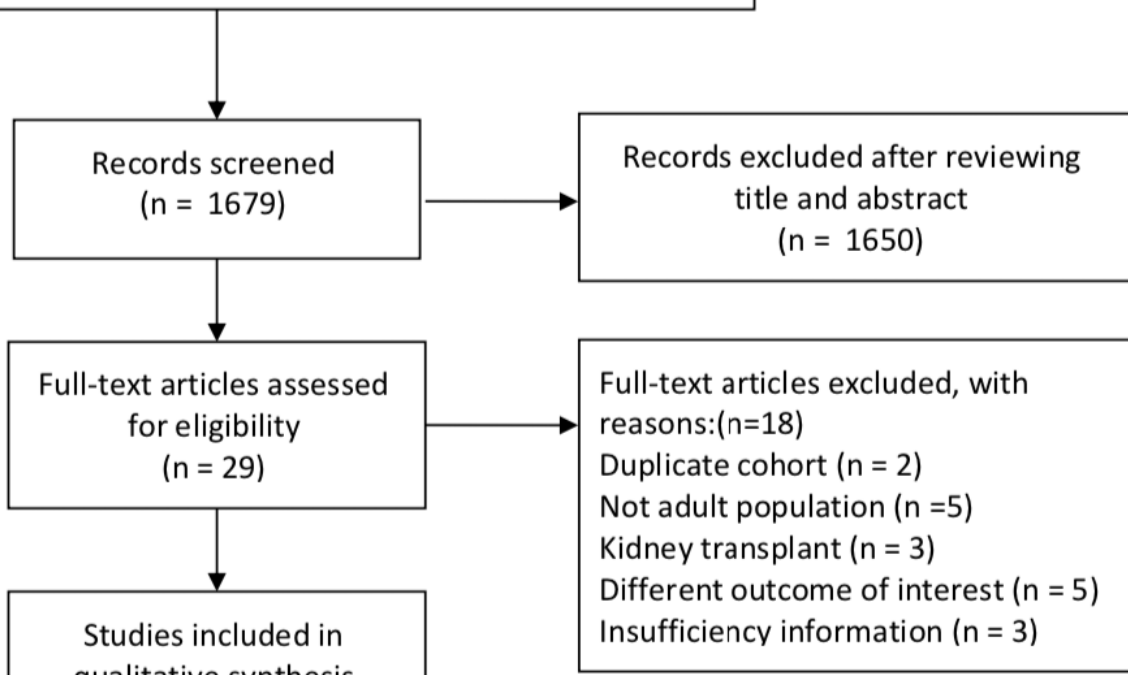

qualitative synthesis

$(n=11)$

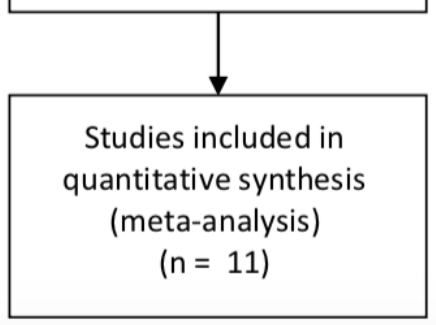

ull-text articles excluded, with

reasons: $(n=18)$

Not adult population $(n=5)$

Different outcome of interest $(n=5)$

Insufficiency information $(n=3)$

Figure 1

PRISMA Flow chart of study inclusion 

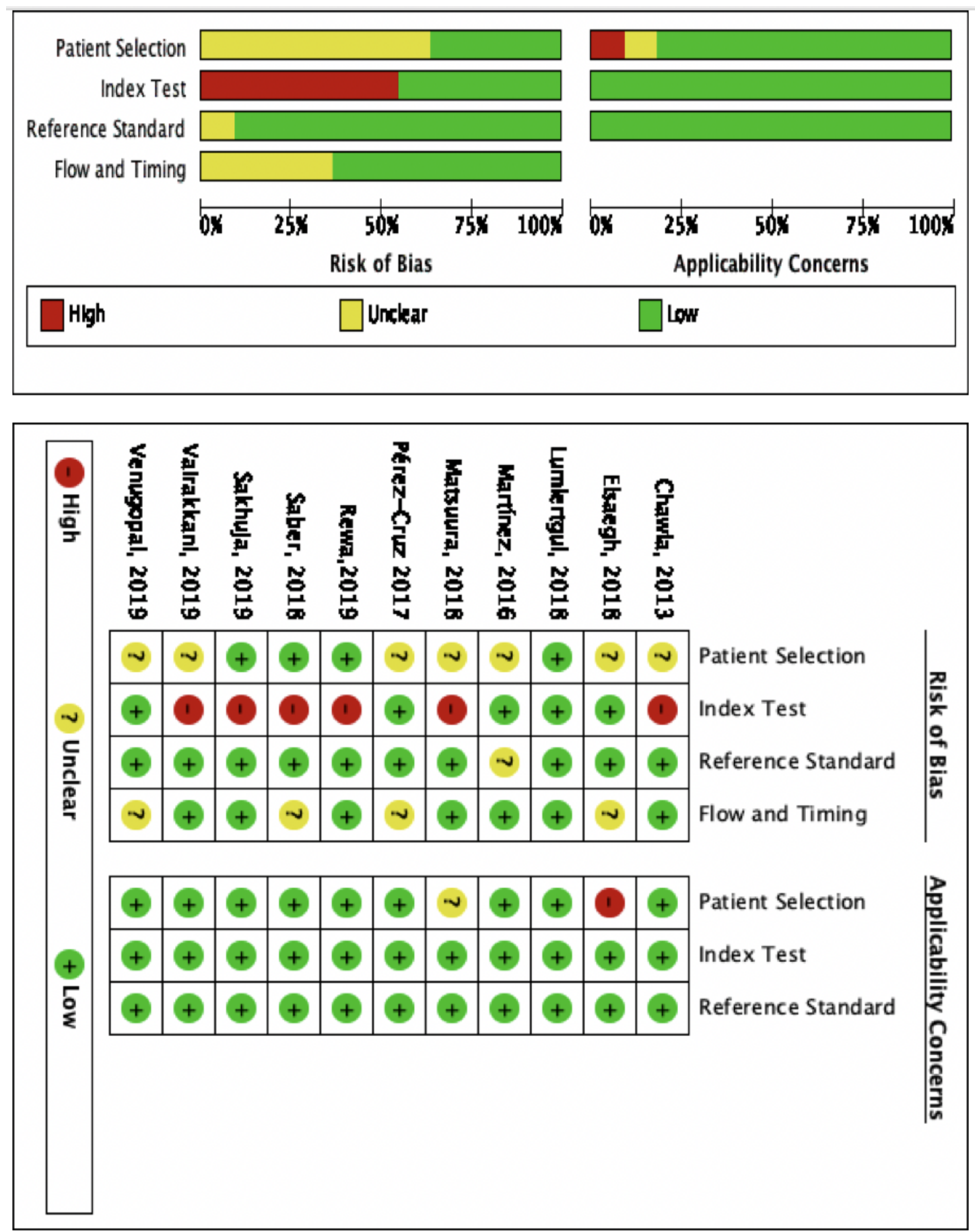

Figure 2

Summary of risk of bias and applicability concern 


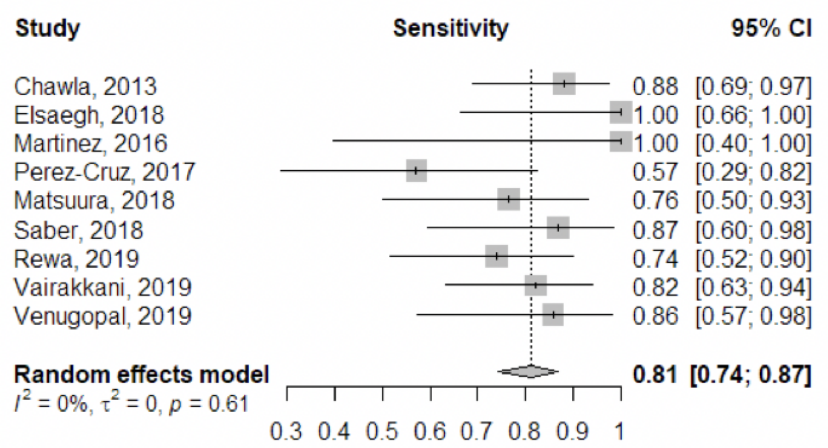

Study

Specificity

$95 \% \mathrm{Cl}$

Chawla, 2013

Elsaegh, 2018

Martinez, 2016

Perez-Cruz, 2017

Matsuura, 2018

Saber, 2018

Rewa, 2019

Vairakkani, 2019

Venugopal, 2019

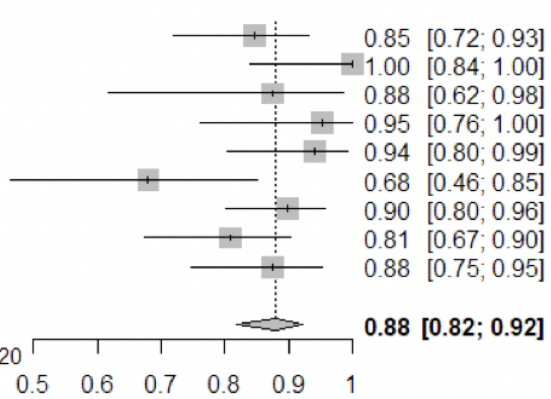

Random effects model

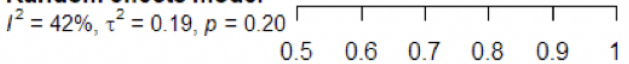
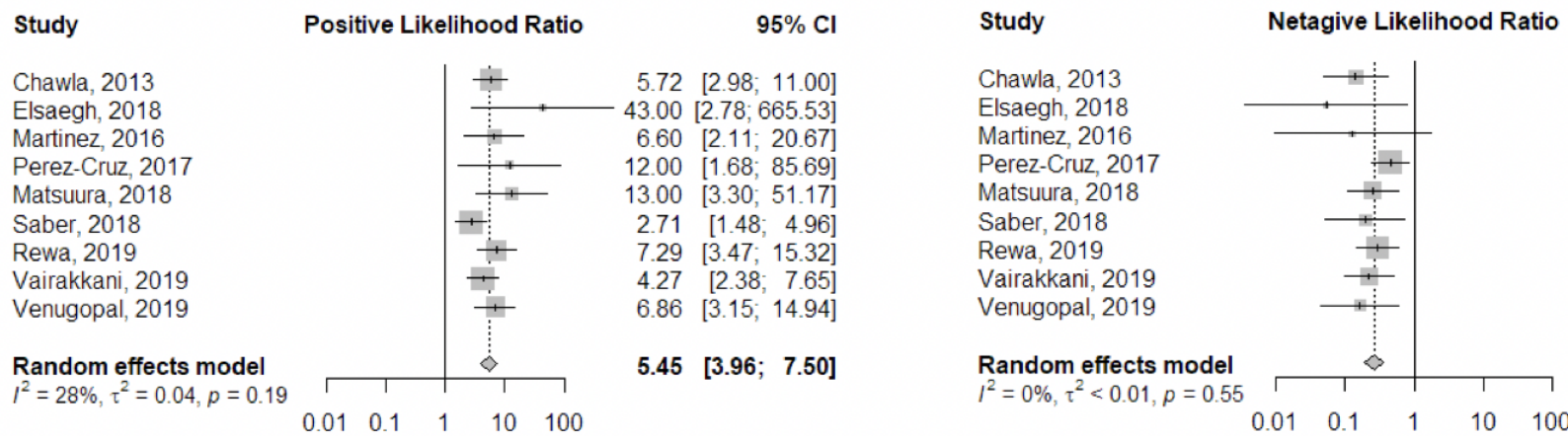

$95 \% \mathrm{Cl}$

$0.14[0.05 ; 0.41]$

$0.05[0.00 ; 0.78]$

$0.13[0.01 ; 1.74]$

$0.45[0.24 ; 0.83]$

$0.25[0.11 ; 0.59]$

$0.20[0.05 ; 0.73]$

$0.29[0.15 ; 0.58]$

$0.22[0.10 ; 0.49]$

$0.16[0.05 ; 0.59]$

$0.26[0.19 ; 0.36]$

Figure 3

Forest plot of FST diagnostic accuracy for AKI progression prediction

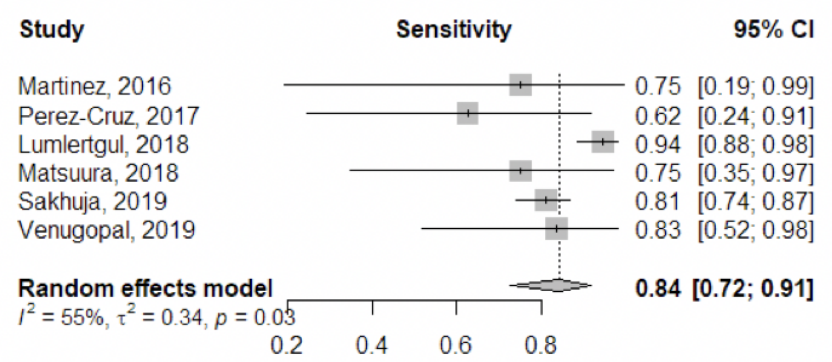

Study

Specificity

$95 \% \mathrm{Cl}$

Martinez, 2016 Perez-Cruz, 2017 Lumlertgul, 2018 Matsuura, 2018 Sakhuja, 2019

Venugopal, 2019

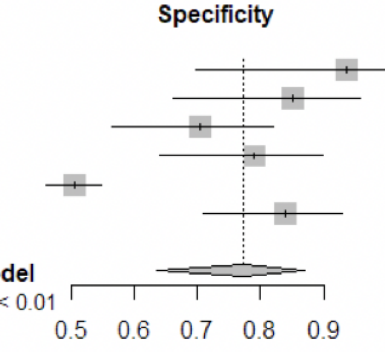

$0.94[0.70 ; 1.00]$ $0.85[0.66 ; 0.96]$

$0.70[0.56 ; 0.82]$

$0.79[0.64 ; 0.90]$

$0.50[0.46 ; 0.55]$

$0.84[0.71 ; 0.93]$

Random effects mode

$0.77[0.64 ; 0.87]$

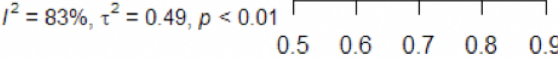

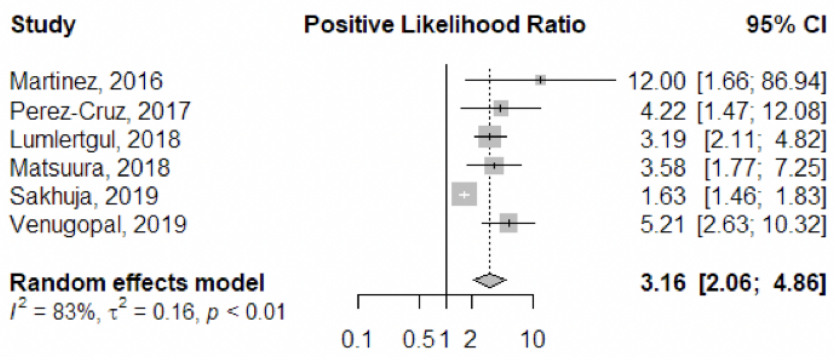

Study

Martinez, 2016

Perez-Cruz, 2017

Lumlertgul, 2018

Matsuura, 2018

Sakhuja, 2019

Venugopal, 2019

Random effects model $1^{2}=64 \%, \tau^{2}=0.23, p=0.02$
Netagive Likelihood Ratio

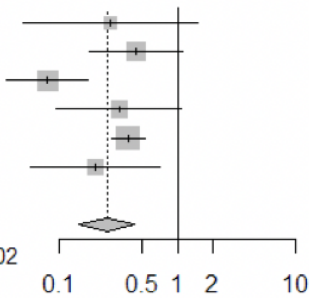

$95 \% \mathrm{Cl}$

$0.27[0.05 ; 1.46]$

$0.44[0.18 ; 1.09]$

$0.08[0.04 ; 0.18]$

$0.32[0.09 ; 1.06]$

$0.38[0.27 ; 0.53]$

$0.20[0.06 ; 0.71]$

$0.25[0.14 ; 0.44]$

Figure 4

Forest plot of FST diagnostic accuracy for renal replacement therapy prediction 
This is a list of supplementary files associated with this preprint. Click to download.

- Additionalprofile1SupplTablemajorrevision20200326.docx

- GRADEmajorrevision.pdf

- SupplDocument1CCmajorrevision.docx

- PROSPEROmajorrevision.pdf

- SupplFig7MortalitySROC.tif

- SupplFig3RRTDOR.tif

- SupplFig6MortalityDOR.tif

- SupplFig1AKIDOR.tif

- SupplFig4RRTSROC.tif

- SupplFig10SenSROC.tif

- SupplFig8Senoutcome.tif

- SupplFig2AKISROC.tif

- SupplFig5Mortalityoutcome.tif

- SupplFig9SenDoR.tif 